\title{
The Effects of The Problem-Based Learnıng Supported by Experiments in Science Course: Students' Inquiry Learning and Reflective Thinking Skills
}

\author{
Huriye Deniş-Çeliker ${ }^{*}$, Seda Dere ${ }^{2}$ \\ ${ }^{1}$ Department of Mathematics and Science Education, Faculty of Education, Burdur Mehmet Akif Ersoy University, Burdur, Turkey \\ ${ }^{2}$ Hamidiye Secondary School, Afyonkarahisar, Turkey \\ *Corresponding Author. huriyedenis@mehmetakif.edu.tr
}

\begin{abstract}
This study aims to investigate the effect of the problem-based learning method supported by experiments on the inquiry learning skills of secondary school students and their reflective thinking skills for problem-solving. This research uses a quasi-experimental design with a pretest-posttest control group. This study consists of 21 students in the experimental group and 22 students in the control group from the sixth grade of a public secondary school in Turkey. The inquiry learning skills and reflective thinking skills scale for problem-solving were used as data collection tools in the research. The Electricity Transmission unit was carried out in the experimental group with problem-based learning scenarios supported by the experiment. Activities based on the science course curriculum were carried out in the control group. SPSS-21 was used to analyze the data. As a result of the study, it was concluded that the post-test scores of the inquiry learning skills scale of the students in the experimental group differed statistically significantly from those of the control group students, and this difference was in favor of the experimental group. No significant difference was found between the experimental and control groups in post-test scores regarding reflective thinking skills for problem-solving.
\end{abstract}

Keywords Problem-based learning supported with experiment, Inquiring learning skills, Reflective thinking skills, Science education

\section{INTRODUCTION}

There are skills that individuals living in the 21 st century must have to survive in business life. 21st-century skills express the characteristics that enable individuals to become good citizens and qualified workers in the information society of this century (Cansoy, 2018). Individuals who are today's students will be adults of the future. Some professions that exist today will disappear, and new jobs will emerge. In this respect, it is stated that it is essential for students to prepare for new professions and acquire these skills by creating quality learning times rather than transferring a lot of information in schools (Organisation for Economic Co-operation and Development [OECD], 2018). One of the aims of science education is to raise individuals with critical, creative, questioning, reflective, and high problem-solving skills among 21st-century skills.

It is necessary to comprehend the importance of science by developing their inquiry skills to provide students with 21 st-century skills. Science course is an inquiry-based course by its nature (Okumuş \& Yetkil, 2020). Therefore, it is necessary to use science courses effectively to develop inquiry skills (Yaşar \& Duban, 2009). Inquiry skills are defined as asking questions about the learned subject, searching for responses, generating and creating the latest information while gathering information about any topic, and reflecting on experiences (Taşkoyan, 2008). Inquiry learning is also a lifelong learning skill that allows students to learn meaningfully and permanently by researching and questioning (İnel-Ekici, 2017). It has been determined that students who make inquisitorial reflection spend more time on problem-solving processes and control and organize their problem-solving strategies more (Wopereis, Brand-Gruwel, \& Vermetten, 2007). Raising students with such skills requires their close relationship with inquiry-based learning (IBL) (Howe, 2002).

Received: 10 February 2021

Revised: 19 October 2021

Published: 1 March 2022 
The questions asked in international exams such as the Program for International Student Assessment (PISA) and Trends in International Mathematics and Science Study (TIMSS) require students to use their inquiry skills and establish the context of knowledge and daily life. Countries that are successful in these exams include these skills in their teaching processes (Firman, Ertikanto \& Abdurrahman, 2018). In these international exams, students in Turkey are below the average (Ministry of National Education, 2009, 2011a, 2011b, 2012, 2015a, 2015b, 2018). According to the results of this exam, students do not have enough critical thinking and inquiry skills (Dolapçığlu, 2020; Baran, Baran \& Maskan, 2018). Inquiry learning requires the active participation of students in the process (Balım, İnel \& Evrekli, 2008). At the heart of an inquiry-based class is questioning (Stotter \& Gillon, 2011). Inquiry-based learning can be applied with different methods like case-based learning, project-based learning, and problem-based learning (Bezen \& Bayrak, 2020). For the PBL process to be carried out effectively, students should have the ability to learn by inquiry or develop these skills of students over time (Uden \& Beaumont, 2006). While working towards the problem's solution, students build content knowledge and problemsolving skills (Hung, Jonassen, \& Liu, 2008).

Inquiry learning skills (ILS) are one of these skills. Scientific inquiry involves researching natural phenomena through higher-order thinking skills or experimentation (Lee, Hart, Cuevas, \& Enders, 2004). For this reason, inquiry learning appears in research on science teaching (Howes, Lim, \& Campos, 2009). IBL is the process of problem-solving by asking questions, researching and analyzing information, and transforming learned information into useful information (Zion \& Sadeh, 2007). Inquiry learning in science improves students' perception skills by using their mental and physical skills to explain the results and explanations about events in nature and the World (Harlen, 2004). Therefore, laboratory applications are essential in science lessons (Hofstein \& Lunetta, 2004). It has been proven by many studies that laboratory activities carried out on an interrogative basis are more effective in the development of many cognitive and affective skills (Hofstein, Shore, \& Kipnis, 2004; Akpinar \& Yildız, 2006; Duru, Demir, Önen, \& Benzer, 2011). The inquiry learning process begins with questions that can answer using observation or experimentation data (Yildirim \& Can, 2018). The laboratory application, in which students investigate the teacher's problem through a procedure they designed, is problem-based (Bell, Smetana, \& Binns, 2005). It requires reflective thinking to conduct an inquiry and understand the entire inquiry process (Van der Schaaf, Baartman, Prins, Oosterbaan \& Schaap, 2013).

As a result of confronting students with problem situations, critical awareness will be created, and reflective thinking skills (RTS) will develop. In this respect, the problem-solving process is directly related to the deliberative thinking process (Demirel, Derman, \& Karagedik, 2015; Albayrak, Şimsek, \& Yazıc1, 2018), and it encourages students to maintain their interests (Epstein, 2003). Reflective thinking enables students to show highlevel thinking skills to understand and solve a problem (Song, Grabowski, Koszalka, \& Harkness, 2006). In the problem-solving process, reflection can be seen (Wilson \& Jan, 1993). Therefore, using RTS in problem-solving helps to provide more in-depth learning and increase awareness in these processes (Junsay, 2016).

RTS is not a spontaneous type of thinking (Alp \& Taşkın, 2008). Reflective thinking is a cognitive feature that is learned and developed consciously (Durdukoca \& Demir, 2012). Therefore, acquiring this skill in the school environment (Demiralp, 2010). RTS emerge most often when encountering a non-routine problem, in learnercentered environments, or when students are active and involved in collaborative problem solving (Mezirow, 1997). In the reflective thinking process, inquiry, reasoning, and evaluation actions are taken (Mansvelder-Longayroux, Beijaard, Verloop \& Vermun, 2007). Reflection is considered a fundamental way of thinking for teaching and learning and encourages thinking of problems from multiple angles. Thus, it includes rethinking unexpected issues to see the experience differently (Ekiz, 2006).

Educational theorists suggested that reflective thinking and similar reflection methods should improve students' decision-making skills in all classes (Kuhn, 1990). RTS; the individual's ability to put forward many thoughts for the problems s/he faces, question these thoughts, and make evaluations by using their past and present experiences (Kember et al., 2000). Based on the idea that reflective thinking will occur when a problem is encountered, the researchers discussed the RTS for problem-solving in their studies (Bayrak \& Usluer, 2011; Yenilmez \& Turgut, 2016). RTS for problem-solving is an effective high-level thinking style of reflective thinking that is performed from understanding the problem to solving the problem in problem-solving (Sayg1l \& Atahan, 2014). There is a significant relationship between elementary school students' RTS and their academic achievement in science and mathematics (Baş, 2013; Baş \& Kıvilcım, 2013). However, the students' general reflective thinking skills were low in Turkey (Erdoğan, 2019). Similarly, Kholid, Sa'dijah, Hidayanto, \& Permadi (2020) determined that 21 out of 140 mathematics students used reflective thinking skills. The primary school teacher candidates have moderate levels of reflective thinking in science concepts and do not have high-level reflective thinking skills (Bozan, 2021). It requires reflective thinking to conduct an inquiry and understand the entire inquiry process (Van der Schaaf, Baartman, Prins, Oosterbaan \& Schaap, 2013).

Based on the relevant literature, inquiry learning skills and reflective thinking processes are related to problem- 
solving. In addition, it is expected that the experimental courses will be practical on inquiry skills. One of the methods that will enable problem-solving processes in educational environments is problem-based learning (PBL). PBL is an educational method that allows students to be active participants in the learning process and advocates learning subjects and concepts related to learning areas by solving their problems (Smith \& Hung, 2017). PBL is a method that is organized around the solution of open-ended real-life issues in a subject that students have not learned before and is based on learning experiences that enable students to learn by practicing and experiencing (Hmelo \& Ferrari, 1997; Marklin-Reynolds \& Hancock, 2010; Lu, Lajoie, \& Wiseman, 2010). PBL assumes that the learner learned how to determine their knowledge about a perceived problem, identified their learning needs, and determined how to obtain best the relevant information (Dahlgren \& Öberg, 2001). In this process, the analysis of the problem in the scenarios, problem-solving, cooperative learning with group interaction, reflection, and evaluation of learning results are carried out by students (Huang, Huang, Wu, Chen, \& Chang, 2016).

The purpose of the PBL is to help students to construct their knowledge by their knowledge base and to develop the high-level thinking skills needed today (Hmelo-Silver, 2004; Cantürk-Günhan \& Başer, 2009; Usta \& Mirasyedioğlu, 2017). In the PBL method, scenarios are designed to enable students to learn meaningfully, the permanence and transfer of information are supported, and at the same time encouraged to reflect (Onan, 2013). Inquiry learning and reflective thinking processes are expected to be developed with the PBL process supported by experiments.

In the literature, there are studies on the development of a measuring tool for reflective thinking and applied at different education levels (Badger, 2010; Başol \& EvinGencel, 2013; Taşkın-Can \& Yıldırım, 2014) and studies on improving reflective thinking for problem-solving (Hoffman \& Spatariu, 2011; Rieger, Radcliffe, \& Doepker, 2013; Chee-Choy \& San Oo, 2012). There is a significant relationship between secondary school students' ILS towards mathematics and RTS (Katranc1 \& Şengül, 2020). Some inquiry-based studies are related to the development of measurement tools (Wu \& Hsieh, 2006; AldanKarademir \& Saracaloğlu, 2013). Studies support the PBL method with web, computer, and simulation (Belland, 2010; Hwang, Kuo, Chen, \& Ho, 2014; Ioannou, Brown, Hannafin, \& Boyer, 2009). In addition, there are studies at different learning levels supported by concept maps (Johnstone \& Otis, 2006) and concept cartoons (Balım, Deniş-Çeliker, Türkoğuz, Evrekli \& İnel-Ekici, 2015). Yildiz (2010) investigated the effects of practical applications on different variables in solving problembased learning scenarios. It has been determined that the use of PBL supported by experiments in pre-service science teachers has a positive effect on pre-service science teachers' critical thinking skills (Deniş-Çeliker, 2020). Although studies are examining the impact of PBL practices on different variables in science teaching in the related literature, there is no research examining the perception of experimental-supported PBL practices on middle school 6th-grade students' ILS and RTS. Both skills are skills that need to be developed in science teaching. For this reason, science education researchers should research which methods, techniques, and strategies can develop these skills. For this reason, the effect of the experimentally supported PBL method was investigated in this study. This study aimed to determine the impact of the PBL method supported by experiments on students' ILS and RTS towards problem-solving. For this purpose, the following questions will be answered:

1. How is the effect of the PBL method supported by the experiments on secondary school 6th-grade students' ILS scores and RTS for problem-solving scores?

2. How is the effect of lessons taught with the content and activities of the Science Curriculum on secondary school 6th-grade students' ILS scores and RTS for problem-solving scores?

3. Do the effects of the PBL method supported by the experiments and lessons were taught with the content and activities of the Science Curriculum on the ILS scores and RTS for problem-solving scores of secondary school 6th-grade students differ?

4. Is there a significant difference between the experimental and control groups according to the posttest scores of the ILS scale sub-dimensions?

5. Is there a significant difference between the experimental and control groups according to the posttest scores of the RTS sub-dimensions for the problem-solving scale?

6. Is there any relationship between ILS scores and RTS for problem-solving scores?

\section{METHOD}

\subsection{Research Design}

A quasi-experimental design with pre-test, post-test control groups (Karasar, 2003) was used in the research. Creswell (2003) states that whether the subjects will be in the experimental or control group should be determined by a completely random assignment method in the experimental process. The testing method is summarized in Table 1.

\subsection{Participants}

In the 2015-2016 academic year, the research participants at a secondary school constitute Grade 6 students located in the Burdur province in Turkey. The experimental group consists of 21 students studying in the $6 \mathrm{D}$ class of this secondary school, while the control group consists of 22 students studying in the $6 \mathrm{~A}$ class of the same school. In addition, 12 of the students in the experimental 
Table 1 Quasi-experimental research pattern of the study

\begin{tabular}{|c|c|c|c|c|}
\hline Group & Pre-test & Method & Time Period & Post-test \\
\hline Experimental & ILSS & Problem-based learning supported by & 4-5 weeks (16 & ILSS \\
\hline & RTSSPS & $\begin{array}{l}\text { an experiment in Conduction of } \\
\text { Electricity unit. }\end{array}$ & class hours) & RTSSPS \\
\hline Control & & $\begin{array}{l}\text { Lessons carried out activities based } \\
\text { on the science lesson curriculum. }\end{array}$ & & \\
\hline
\end{tabular}

ILLS Inquiry Learning Skills Scale RTSSPS Reflective Thinking Skills Scale for Problem-solving

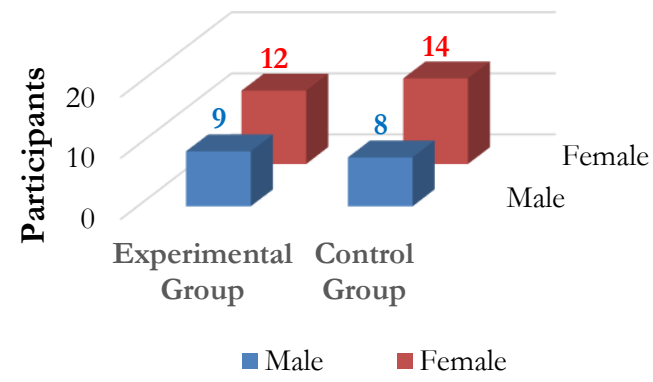

Figure 1 Distribution of participants by gender

group were female, and nine were male (See in Figure 1). Of the students in the control group, 14 were female, and 8 were male. In Turkey, the end-of-term grade of the courses in secondary school is scored as a maximum of 5 and a minimum of 1 . The participants' distribution according to the previous semester's science course averages is presented in Figure 2. All participants are 12 years old.

\subsection{Data Collection Tools}

\subsubsection{Inquiry Learning Skills Scale}

The research used the "Inquiry Learning Skills Perception Scale for Science" developed by Balım \& Taşkoyan (2007). The scale consists of 22 perception items. The scale consists of three sub-factors. These are the negative perception items dimension with a Cronbach's alpha reliability coefficient of 0.73 , the dimension of positive perception items with a reliability coefficient of 0.67 , and the sense of questioning the accuracy with a reliability coefficient of 0.71 . Cronbach's alpha coefficient for the whole scale is 0.84 . Examples of scale items are given below:

-I argue with my friends to decide the accuracy of my experimental results.

- Experiment, which is one of the ways scientists work, seems boring to me.

-I think I have to experiment to get scientific results.

\subsubsection{Reflective Thinking Skills Scale for Problem- solving}

The study used the "Reflective Thinking Skill Scale for Problem-solving" developed by Kızlkaya \& Aşkar (2009), consisting of 14 questions. The scale consists of 14 items and three sub-factors. The Cronbach's alpha value of the inquiry factor was 0.73 , the value of the reason factor was 0.71 , and the value of the element was 0.69 . This value is 0.83 for all scale items. Examples of the things of the scale are given below:

- When I cannot solve a problem, I ask myself questions to understand why I cannot solve it.

- When I read a problem, I think about what information I need to solve it.

- After solving the problem, I compare it with the solutions of my friends and evaluate my result.

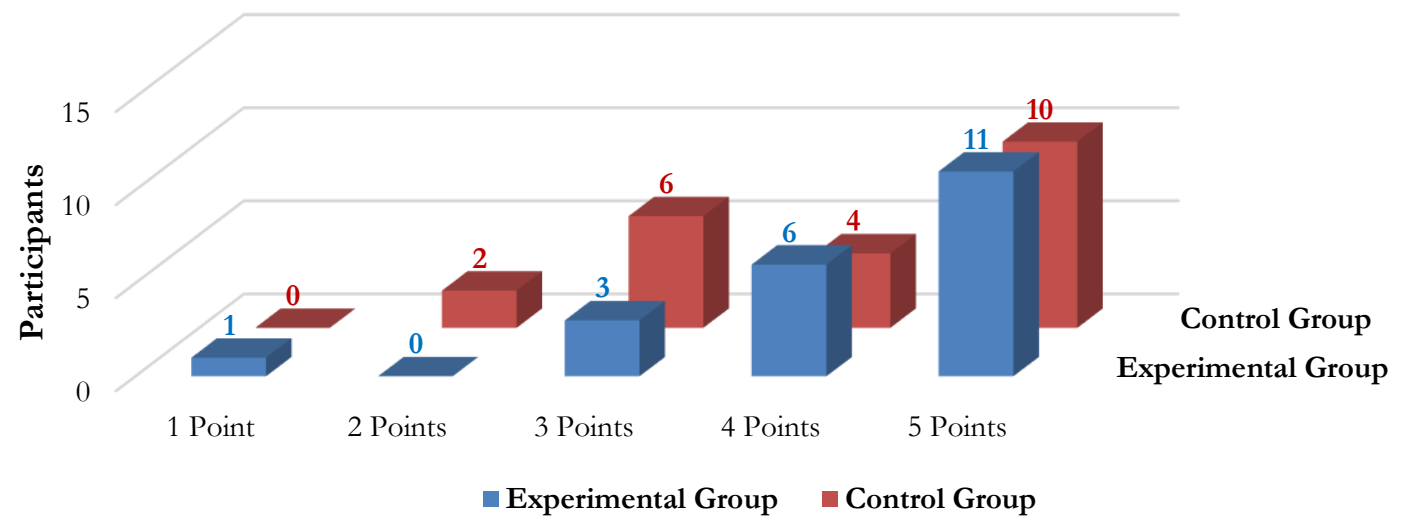

Figure 2 The distribution of the participants according to the science course averages of the previous semester 


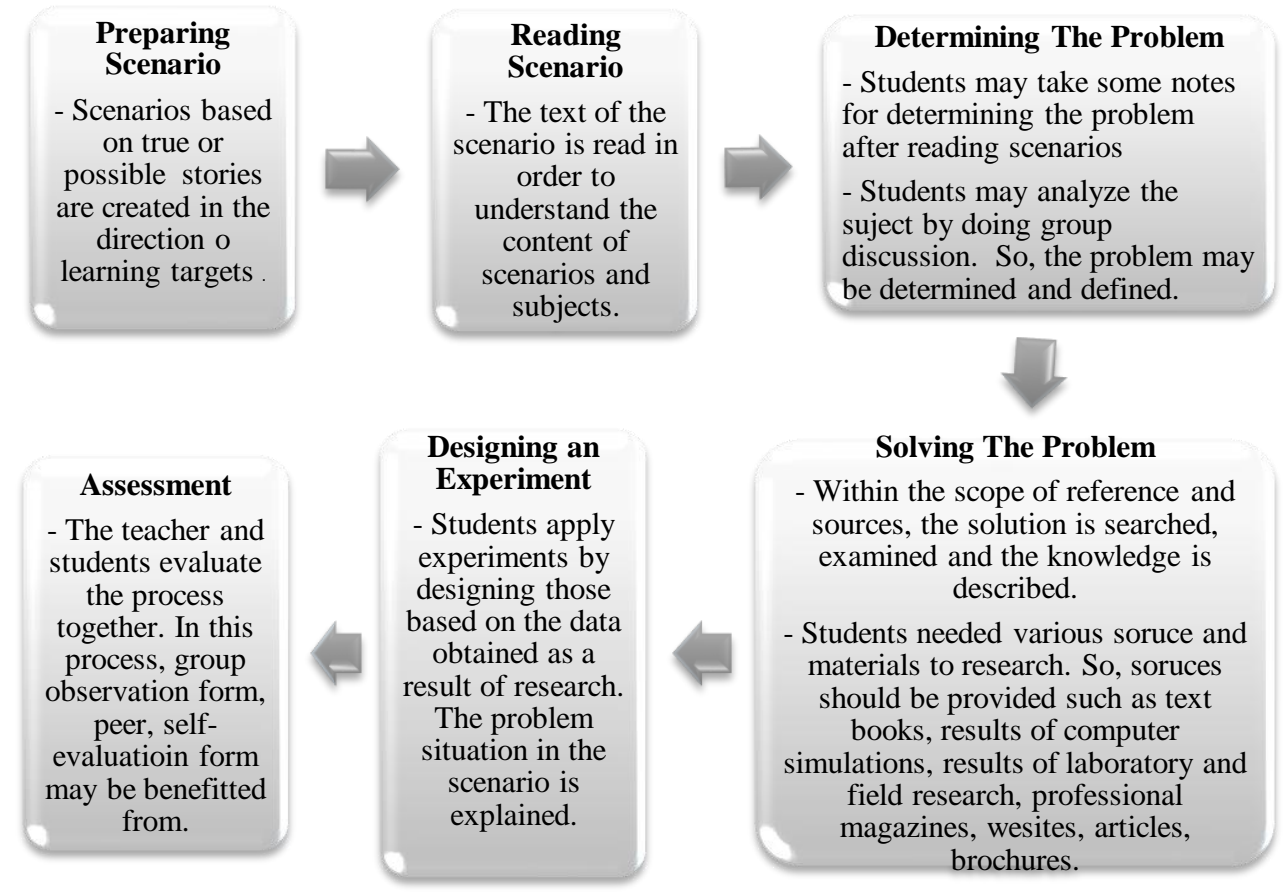

Figure 3 The stages phases of problem-based scenarios with experiments

\subsection{The Experimental Group Implementation}

The research was carried out in the "Conduction of Electricity" unit in the 6th-grade science lesson. The tasks were carried out with the PBL method supported by experiments during the experimental group unit. For the experimental group to adapt to the problem-based learning process and to eliminate possible malfunctions, the last topic of the previous unit was covered with a module consisting of three scenarios. Thus, the team is completed in two modules, seven sessions. The first module, Conductors / Insulators, consists of 4 procedures. The second module consists of 3 scenarios on resistance. Based on the scenarios, the students were asked to design seven experiments. Since problem-based scenarios were applied together with the experiments in the science lesson, the experiment phase was added to the process. The application was made according to the steps specified by Deniş-Çeliker (2021), which is indicated in Figure 3.

As seen in Figure 3, the scenario was prepared first. Then the students read the plan and identified the problem. Next, they designed experiments to solve the problem and reveal their solutions. Finally, observation form, peer and self-assessment, and process assessment were made at the last stage.

One of the scenarios used in the study is presented below:

Aylin and her family boarded a fully equipped passenger plane to visit her aunt in America. While the plane was underway, it had to make an emergency landing on an island in the Pacific Ocean due to a malfunction in its engine. Passengers thought about how the planes flying over the island to get off the island might get their attention. Aylin: "Let's set up a simple electrical circuit. Noticing the light, the planes can save us. " she said. Passengers brought a 100-watt light bulb and 50-meter cable from the plane.

1. Passenger, copper, and short cable;

2. Passenger, copper, and extended cable;

3. Passenger brings nickel-chrome and cable as long as the 1st passenger.

Aylin was surprised to see that the brightness of the bulbs in the prepared circuits was not the same.

The questions asked about the scenario are given below:

- What is the problem to be addressed in the system?

- What information can we research to solve the situation in the design?

- What do we know?

- What could be the reason for the different brightness of the bulbs?

- Are there other factors affecting the brightness of the bulb?

- Why are copper and aluminum wires preferred in electrical circuits?

- Design 3 different experiments in which you can observe the effect of the length of the wire, the cross-section of the wire, and the type of wire on the resistance. Describe your experimental setups by drawing.

During the experimental studies, the photographs taken while the students were working in groups, designing their experiments, and filling out the worksheets are presented below in Figure 4.

\subsection{The Control Group Implementation}

The lessons carried out activities based on the science lesson curriculum in the control group. Since 2005, the science curriculum in Turkey has been prepared based on the student-centered constructivist approach. Activities in 


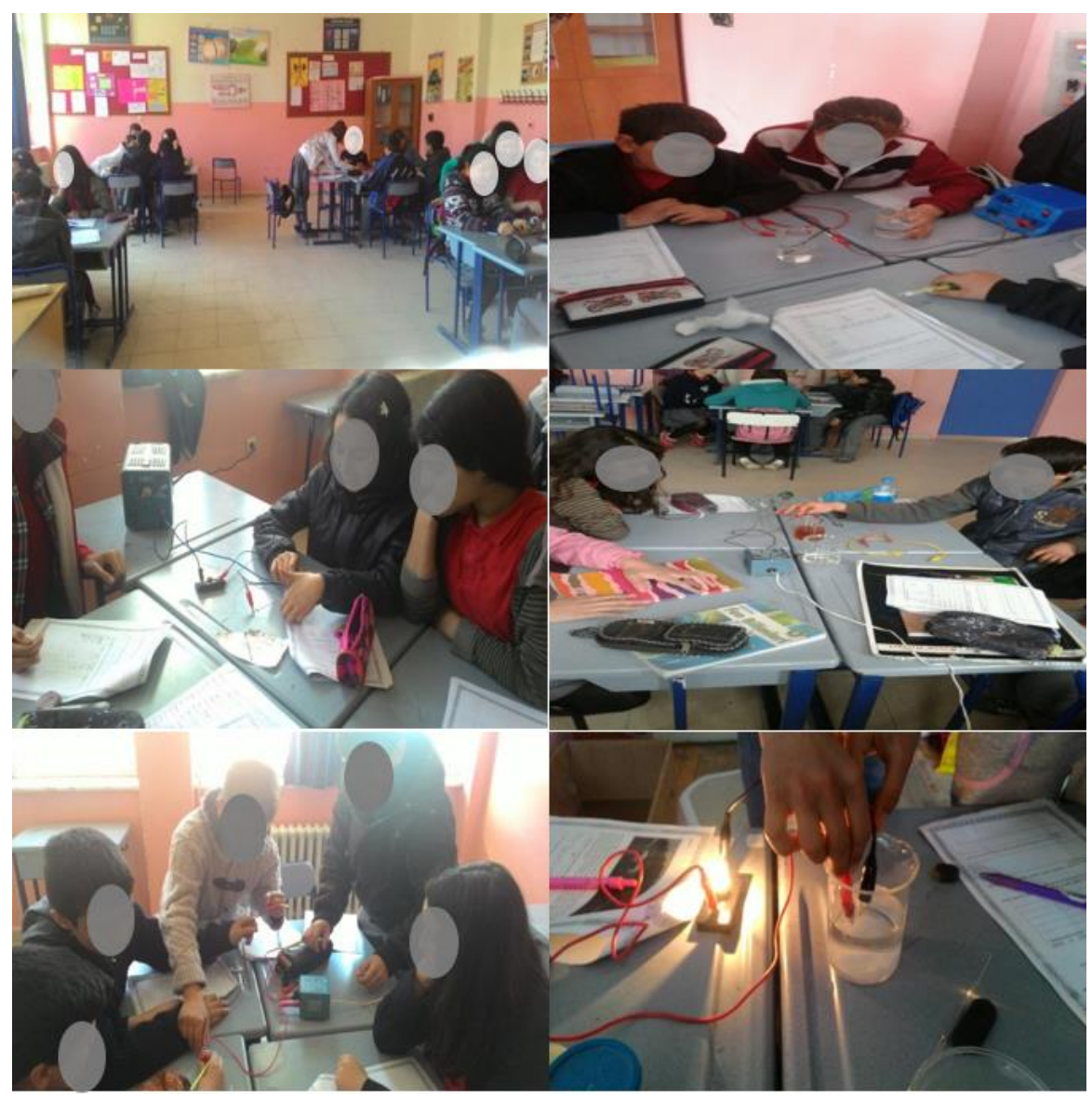

Figure 4 Some photos of students during experimental studies

this group included activity exercises in official textbooks, smartboard exercises, listening to the teacher, and answering questions. Students in this group did an experiment based on the book. They didn't design the experiment themselves. Often observed by the students who made teacher experiment in demonstration experiments.

\subsection{Students Outcomes of the Unit}

The students are expected to achieve the following achievements with this unit (Ministry of National Education, 2013):

\subsubsection{Conductive and Insulating Materials \\ Recommended Duration: 6 lesson hours}

Subject / Concepts: Conductive materials, insulating materials, conductive and insulating materials usage areas

2.6.1.1. The student classifies materials according to whether they conduct electricity or not by using the electrical circuit s/he designed.

2.6.1.2. Explain with examples from daily life for which purposes the electrical conductivity and insulating properties of materials are used.

\subsubsection{Electrical Resistance and Related Factors \\ Recommended Duration: 10 lesson hours}

Subject / Concepts: Electrical resistance, factors on which electrical resistance depends (cross-sectional area, length, type of conductor)
2.6.2.1. Estimates the variables on which the light bulb's brightness in an electrical circuit depends and tests its predictions by experimenting.

2.6.2.2. It measures the resistance of a conductor by expressing electrical resistance and specifies its unit.

2.6.2.3. $\mathrm{S} /$ he realizes that the bulb is also composed of a conductive wire and has resistance.

\subsection{Data Analysis}

The research was conducted with two groups, an experiment, and a control. The data collected from these groups were analyzed. The Statistics Package for Social Sciences 21.0 (SPSS) was used to evaluate the study's data. Since the data didn't deviate significantly (excessively) from the normal distribution, for comparison of the pre-test and post-test scores, independent samples t-test, pairedsamples t-test, and MANOVA were used. In addition, whether there is a relationship between the students' ILS scores and RTS for problem-solving scores has been determined by using Pearson Product-Moment Correlation.

\section{RESULT AND DISCUSSION}

\subsection{The Result and Discussion for the first research question}

A comparison of the experimental group's pre-test and post-tests of ILS is presented in Table 2, and the 
Table 2 The paired samples t-test results regarding the comparison of the pre-test - post-test ILS scores of the students in the experimental group

\begin{tabular}{lllllll}
\hline Measurement & $\mathbf{N}$ & $\mathbf{x}$ & $\mathbf{s d}$ & $\mathbf{d f}$ & $\mathbf{t}$ value & $0.00^{*}$ \\
\hline Pre-Test & 21 & 87.66 & 13.72 & 20 & -4.88 & \\
Post-Test & 21 & 98.52 & 8.28 & & \\
\hline
\end{tabular}

$*_{\mathrm{p}}<0.05$ difference is significant. Cohen $\mathrm{d}=0.95$

Table 3 The paired samples t-test results regarding the comparison of the pre-test - post-test RTS scores of the students in the experimental group

\begin{tabular}{lllllll} 
Measurement & $\mathbf{N}$ & $\mathbf{\mathbf { x }}$ & $\mathbf{s d}$ & $\mathbf{d f}$ & $\mathbf{t}$ value & $\mathbf{p}$ \\
\hline Pre-Test & 21 & 50.61 & 12.94 & 20 & -3.04 & $0.006^{*}$ \\
Post-Test & 21 & 59.80 & 7.21 & & \\
\hline
\end{tabular}

${ }^{*} \mathrm{p}<0.05$ difference is significant. Cohen $\mathrm{d}=0.88$

Table 4 The paired samples t-test results regarding the comparison of the pre-test - post-test ILS scores of the students in the control group

\begin{tabular}{lllllll}
\hline Measurement & $\mathbf{N}$ & $\mathbf{x}$ & sd & df & t value & P \\
\hline Pre-Test & 22 & 83.04 & 8.84 & 21 & 0.423 & 0.67 \\
Post-Test & 22 & 82.09 & 7.06 & & &
\end{tabular}

$\mathrm{p}>0.05$

Table 5 The paired samples t-test results regarding the comparison of the pre-test - post-test RTS scores of the students in the control group

\begin{tabular}{lllllll}
\hline Measurement & $\mathbf{N}$ & $\mathbf{x}$ & $\mathbf{s d}$ & $\mathbf{d f}$ & $\mathbf{t}$ value & p \\
\hline Pre-Test & 22 & 54.63 & 5.07 & 21 & -1.206 & 0.24 \\
Post-Test & 22 & 57.09 & 6.92 & & &
\end{tabular}

comparison of RTS's pre-test and post-tests is shown in Table 3.

Table 2 The paired samples t-test results regarding the comparison of the pre-test - post-test ILS scores of the students in the experimental group.

A significant increase was found in students' ILS after PBL practices supported by experiments $\left[\mathrm{t}_{(20)}=-4.88, \mathrm{p}<\right.$ 0.05]. This finding shows that PBL application supported by experiments had a significant effect on improving students' ILS were shown in Table 2. The results revealed that the impact of the PBL method supported by experiments on the development of students' perceptions of ILS was statistically significant. PBL prepares the ground for developing students' inquiry thinking skills through problems (Barrows, 1996). Kamin, O'Sullivan, Younger, \& Deterding (2001) stated in their study that students' defining issues and logically evaluating solutions in the process of problem-solving could improve their inquiry skills. In the PBL process, students use high-level thinking skills such as inquiry learning and problem-solving (Inel, 2012).

As seen in Table 3, when the pre-test post-test RTS scores of the experimental group were compared, there was a significant difference in favor of the post-tests. Thus, developmentally and age-appropriate problem-based learning environments that support reflective thinking should be designed. Furthermore, they argued that problem-based learning includes a mechanism that increases reflective thinking (Song, Grabowski, Koszalka,
\& Harkness, 2006). In this study, a significant difference was found between the pre-test and post-test scores of the experimental group in which PBL was applied.

Methods such as learning diaries, concept maps, asking questions, collaborative learning, self-evaluation, Interview, Portfolio (Student Product File), Peer Review, Discussion, Observation, Seminar Studies, Oral Presentations, Autobiography, Drama, Visual Presentations used to develop reflective thinking (Kazu \& Demiralp, 2012). The experimental group conducted selfassessment, peer evaluation, questions, and discussion during the PBL process. That can explain the increase in the experimental group itself.

\subsection{The Result and Discussion for the second research question}

A comparison of the control group's pre-test and posttests of ILS is presented in Table 4, and the comparison of RTS's pre-test and post-tests is shown in Table 5.

Table 4 The paired samples t-test results regarding comparing the pre-and post-test ILS scores of the students in the control group.

When the pre-test-post-test inquiry learning skill scores of the students in the control group were compared, it was concluded that there was no statistically significant difference seen in Tablo 4. Likewise, there was no statistically significant difference between the experimental and control group students' pre-tests ILS scores.

When the pre-test-post-test reflective thinking scale scores of the students in the control group were compared, 
it was concluded that there was no statistically significant difference were shown in Table 5. Teachers believe that the curriculum's learning environment and evaluation process, in general, positively affect the development of students' reflective thinking (Demiralp \& Kazu, 2012). Since 2005, the science curriculum in Turkey has been prepared based on the student-centered constructivist approach. For this reason, there are activities based on developing reflective thinking in the textbook. Although not statistically significant, there was an increase in the reflective thinking skill scores of the control group students in this study.

\subsection{The Result and Discussion for the third research question}

The comparison of the pre-test ILS scale of the experimental and control groups is presented in Table 6, and the post-tests are shown in Table 7.

As seen in Table 6, students' pre-test inquiry learning skill scores didn't differ according to the experimental and control groups.

Students' post-test inquiry learning skill scores differed significantly according to the group $[\mathrm{t}(41)=7.01, \mathrm{p}<0.05]$. Experimental group students' post-test inquiry learning skill scores were higher than control group students were shown in Table 7.

After the practical application, there was a statistically significant difference in favor of the experimental group. The teachers used the textbook as the primary source in the control group. Textbooks have traditionally focused on memory and learning responses rather than inquiry skills (Reaume, 2011). However, the students in the experimental group determined the problem based on the scenario and designed an experiment to solve this problem may have impacted their inquiry learning skills. The students in the experimental group had to use their inquiry learning skills. It has been revealed that the effect of problem-based learning on inquiry thinking skills is similar (Kang, DeChenne \& Smith, 2012). Inel (2009) reached a similar conclusion. Inquiry activities improve students' inquiry skills, especially identifying a method and getting a result (Cuevas, Lee, Hart, \& Deaktor, 2005).

IBL can be expressed as a student-centered process in which students identify problems, create problems, and try to solve problems (Wood, 2003; Maaß, \& Artigue, 2013). The students had to use these skills in the experimentsupported problem-solving process. Karamustafaoğlu \& Havuz (2016), who worked with prospective teachers, reached a similar result. They concluded that the laboratory activities based on IBL increased the future teachers' research inquiry skills in favor of the experimental group. In this study, secondary school students identified the problem themselves, found a solution to the problem they identified, solved it by doing and experiencing, and developed their IBL skills by designing a problem-based experiment. Also, IBL was a practical way to link previous knowledge with definitions of the natural world (Panasan \& Nuangchalerm, 2010).

The comparison of the pre-test RTS scores of the experimental and control groups are presented in Table 8, and the post-tests are shown in Table 9.

As seen in Table 8, pre-test RTS scores of the students didn't differ between the experimental and control groups.

Post-test RTS scores of students didn't differ between the experimental and control groups were shown in Table 9 .

Table 6 Independent t-test results comparing the groups' pre-test ILS scale scores

\begin{tabular}{lllllll}
\hline Group & $\mathbf{N}$ & $\overline{\mathbf{x}}$ & $\mathbf{s d}$ & $\mathbf{d f}$ & $\mathbf{t}$ value & $\mathbf{p}$ \\
\hline Experiment & 21 & 87.66 & 13.72 & 41 & 0.19 \\
Control & 22 & 83.04 & 8.84 & & & \\
\hline
\end{tabular}

$\mathrm{p}>0.05$

Table 7 Independent t-test results comparing the groups' post-test ILS scale scores

\begin{tabular}{lllllll}
\hline Group & $\mathbf{N}$ & $\mathbf{x}$ & sd & df & t value & p \\
\hline Experiment & 21 & 98.52 & 8.28 & 41 & 0.00 \\
Control & 22 & 82.09 & 7.06 & & \\
\hline
\end{tabular}

$\mathrm{p}<0.05$ Cohen $\mathrm{d}=2.14$

Table 8 Independent t-test results comparing the groups' pre-test RTS scores

\begin{tabular}{lcccccc}
\hline Group & $\mathbf{N}$ & $\overline{\mathbf{x}}$ & $\mathbf{s d}$ & $\mathbf{d f}$ & $\mathbf{t}$ value & $\mathbf{p}$ \\
\hline Experiment & 21 & 50.61 & 12.94 & 25.77 & -1.328 & 0.19 \\
Control & 22 & 54.63 & 5.07 & & &
\end{tabular}

$\mathrm{p}>0.05$

Table 9 Independent t-test results comparing the groups' post-test RTS scores

\begin{tabular}{lllllll}
\hline Group & $\mathbf{N}$ & $\mathbf{x}$ & $\mathbf{s d}$ & $\mathbf{d f}$ & t value & $\mathbf{p}$ \\
\hline Experiment & 21 & 59.80 & 7.21 & 41 & 1.26 & 0.21 \\
Control & 22 & 57.09 & 6.92 & & &
\end{tabular}

$\mathrm{p}>0.05$ 
It was determined that the effect of the PBL method supported by experiments on the development of students' RTS for problem-solving was not statistically significant. Furthermore, there is no significant difference between the experimental and control groups' RTS post-test scores for problem-solving.

The lack of difference in the post-tests of the experimental and control groups may be since the textbook activities applied in the control group also focused on developing reflective thinking. Recently updated teaching programs at our schools positively affect students to acquire reflective thinking skills and inquiry learning (Katranc1 \& Şengül, 2020). This finding was in line with the study results (Dadli, 2017), which examined the effect of authentic PBL activities on secondary school students' RTS. Pusmaz \& Tavşan (2019) stated that students who are successful in problem-solving could show reflections in the themes of feelings/emotions and groupmatesAlthough. However, they were successful in general knowledge, experience, and context pieces.

Nevertheless, they still have difficulty reflecting within the determined indicators, they can remember incompletely, or it was concluded that they could not make a reflection. In developing reflective thinking from preschool to 12th grade, teaching strategy, materials, student independence, collaboration efforts, individual attention of the teacher, and encouraging the student to the lesson are essential (King \& Kitchener, 2004). Despite emphasizing student independence, collaboration, and material used in experiment-supported PBL, it was insufficient to develop students' RTS. In a study, Namvar, Naderi, Shariatmadari, \& Seifnaraghi (2009) found that a problem-solving weblog environment positively affects students' RTS.

\subsection{The Result and Discussion for the fourth research question}

The comparison of the ILS scale pre-test and post-tests of the experimental group is presented in Table 10. Examining the findings in Table 10, there was a difference in favor of the experimental group in the post-tests according to the students' positive perceptions in the experimental and control groups and the scores they received in the factors of questioning accuracy. There was also a significant difference in the negative perceptions factor in favor of the control group. With inquiry-type experiments, students develop many skills, such as asking better questions (Hofstein, Navon, Kipnis, \& MamlokNaaman, 2005).

In a study investigating the effect of argumentationbased PBL on ILS, it was found that the scores of the experimental groups in the positive perception subdimension and the perception of questioning accuracy subdimension were higher than the control groups. However, this difference is insignificant (Yllırım \& Can, 2018). With this difference between the results, it can be concluded that PBL supported by experiments was appropriate in developing ILS sub-factors.

\subsection{The Result and Discussion for the fifth research question}

The comparison of post-test scores of the sub-factors of the RTS scale with the experimental and control groups is presented in Table 11. When the post-test scores of the experimental and control groups were compared in terms of the questioning, assessment, and reasoning sub-factors of the scale, it was found that there was no statistical difference were shown in Table 11.

Table 10 Post-test MANOVA results according to the factors of the experimental and control group students' ILS scale

\begin{tabular}{|c|c|c|c|c|c|c|}
\hline Factor & Group & $\mathbf{N}$ & $\bar{x}$ & sd & $\mathbf{F}$ & $\mathrm{p}$ \\
\hline \multirow[t]{2}{*}{ Positive Perceptions } & Experiment & 21 & 41.28 & 3.59 & 18.04 & $0.00^{*}$ \\
\hline & Control & 22 & 37.00 & 3.00 & & \\
\hline \multirow[t]{2}{*}{ Negative Perceptions } & Experiment & 21 & 10.66 & 2.92 & 47.90 & $0.00^{*}$ \\
\hline & Control & 22 & 20.22 & 5.64 & & \\
\hline \multirow[t]{2}{*}{ Questioning the Accuracy } & Experiment & 21 & 31.90 & 3.03 & 9.30 & $0.04^{*}$ \\
\hline & Control & 22 & 29.31 & 2.51 & & \\
\hline
\end{tabular}

$* \mathrm{p}<0.05$ difference is significant. Positive perceptions Cohen $\mathrm{d}=1.29$; negative perceptions Cohen $\mathrm{d}=, 2.13$; Questioning the truth of Cohen $\mathrm{d}=0.93$

Table 11 Post-test MANOVA results according to the factors of the experimental and control group students' RTS scale

\begin{tabular}{|c|c|c|c|c|c|c|}
\hline Factor & Group & $\mathbf{N}$ & $\overline{\mathbf{x}}$ & sd & $\mathbf{F}$ & $\mathrm{p}$ \\
\hline \multirow[t]{2}{*}{ Questioning } & Experiment & 21 & 21.80 & 2.73 & & \\
\hline & Control & 22 & 20.36 & 3.28 & 2.44 & 0.12 \\
\hline \multirow{2}{*}{ Assessment } & Experiment & 21 & 21.14 & 2.53 & & \\
\hline & Control & 22 & 19.95 & 3.04 & 1.92 & 0.17 \\
\hline \multirow[t]{2}{*}{ Reasoning } & Experiment & 21 & 15.19 & 1.53 & & \\
\hline & Control & 22 & 15.04 & 2.01 & 0.22 & 0.79 \\
\hline
\end{tabular}


Table 12 The Relationship between ILS scores and RTS for problem-solving scores

\begin{tabular}{lllll} 
Measurement & Variables & n & R & p \\
\hline Pre-test & ILS scores & & $0.351^{*}$ & 0.021 \\
Post-test & RTS for problem-solving scores & 43 & $0.311^{*}$ & 0.043 \\
\hline
\end{tabular}

${ }^{*} \mathrm{p}<0.05$

Table 13 Correlation matrix according to subfactors of ILS and RTS for problem-solving scales

\begin{tabular}{lllll} 
Measurement & Factor & Questioning & Assessment & Reasoning \\
\hline Pre-test & \multirow{2}{*}{ Positive Perceptions } & 0.29 & $0.36^{*}$ & $0.31^{*}$ \\
Post-test & & $0.43^{*}$ & $0.45^{* *}$ & 0.21 \\
\hline Pre-test & \multirow{2}{*}{ Negative Perceptions } & 0.11 & 0.12 & 0.01 \\
Post-test & \multirow{2}{*}{ Questioning Accuracy } & 0.54 & 0.08 & 0.07 \\
\hline Pre-test & & 0.30 & $0.39^{* *}$ & $0.39^{* *}$ \\
Post-test & & $0.40^{* *}$ & $0.34^{*}$ & 0.30 \\
\hline
\end{tabular}

${ }^{*} \mathrm{p}<0.05{ }^{* *} \mathrm{p}<0.01$

\subsection{The Result and Discussion for the sixth research question}

The relationship between ILS and RTS and the subfactors of the scales are shown in Table 12 and Table 13. When the relationship between ILS scores and RTS for the problem-solving scores in Table 12 over the pre-test and post-test total scores of the students is examined, it is seen that there is a moderately significant positive relationship between them. Similarly, a moderate positive correlation was found between middle school students' inquiry learning skills and reflective thinking skills for problemsolving (Katranc1 \& Şengül, 2020). In a different study, a positive, significant, and moderate relationship was found between pre-service teachers' critical thinking and reflective thinking skills (Aşkın-Tekkol \& Bozdemir, 2018; Erdoğan, 2020).

According to the sub-factors of the scales is examined in Table 13, the correlation of the pre-test and post-test scores is a moderate positive correlation between the assessment sub-dimension of the RTS for problem-solving scale and the positive perceptions sub-dimension and questioning accuracy sub-dimension of the ILS scale.

The relation between the final ILS scores and final RTS scores in experimental and control groups is shown in Table 14. Table 14 points out a moderate, meaningful, and positive difference between the post-ILS scores and RTS scores in the experimental group. Accordingly, it can be said that students with high final ILS scores also have high RTS scores. Developing students' reflective thinking skills will also enable them to inquiry about their behavior (Karaoğlan-Yılmaz \& Keser, 2016).

There was no relationship between the post-test ILS scores of the control group students and the post-test RTS scores. That can explain by the fact that the ILS scores did not change much, even though the post-test RTS scores of the students in the control group increased.
Table 14 The relation between the post-ILS scores and post-RTS scores in experimental and control groups

\begin{tabular}{llll} 
Group & & $\mathbf{R}$ & $\mathbf{p}$ \\
\hline Experiment & Post ILS & $0.47^{*}$ & 0.032 \\
& Scores & & \\
& Post RTS & \\
Control & Scores & & \\
& Post ILS 0.006 & 0.98 \\
& Scores & \\
& Post RTS & \\
& Scores & \\
\hline
\end{tabular}

${ }^{*} \mathrm{p}<0.05$

\section{CONCLUSION}

Although studies examine the effects of the PBL practices on different science teaching variables in the relevant literature, there is no study examining the perception of the PBL practices supported by experiments on the ILS and RTS of secondary school 6th-grade students. In addition, although studies integrate the PBL approach with different methods and techniques such as concept cartoons, argumentation, mobile applications, and computer technologies, a limited number of studies supported by experiments have been found.

As a result of the research, there was a significant difference in the ILS of secondary school 6th-grade students, in the positive perceptions, negative perceptions, and questioning the accuracy factors, which were subfactors of the ILS scale. Based on this, PBL activities supported by experiments can develop students' ILS in science lessons.

There was no significant difference between the experimental group in which PBL activities were carried out and the control group. The lessons were taught with the science lesson curriculum using the reflective thinking scale post-tests for problem-solving. After the practical application, there was no significant difference in the RTS scale's questioning, assessment, and reasoning sub-factors for problem-solving. Although it is stated in the theoretical 
explanations of the relevant literature that PBL will improve RTS, no significant difference was found between the post-test scores of the experimental and control groups in this exploratory study. Longer practical practice time may be required for the development of RTS. The reasons for this situation can be investigated in different researches. RTS scale for problem-solving was used within the scope of the study. Results can be compared using different RTS scales.

The research is limited to the transmission of the electricity unit of the 6th-grade science course. However, similar applications can be made in the departments related to electricity in the 5th, 7th, and 8th grades, and the results can be compared.

Different researchers and their validity developed the scales used within the scope of the study, and reliability studies were conducted. As a result, different scales of inquiry skills and reflective thinking skills could be used.

Within the scope of the study, data were collected with quantitative data collection tools. Data triangulation can be achieved by incorporating qualitative data collection tools such as interviews and observation into the process. It can be replicated using the mixed research method.

\section{REFERENCES}

Akpinar, E., \& Yildız, E. (2006). Investigation of the effect of openended experimental technique on students' attitudes towards the laboratory. Dokuz Eylül University Buca Faculty of Education Journal, 20, 69-76.

Albayrak, M., Şimşek, M., \& Yazıc1, N. (2018). The predictive power to mathematical success of belief and reflective thinking for problem solving. Journal of Human Sciences, 15(2), 807-815.

Aldan-Karademir, Ç., \& Saracaloğlu, A. S. (2013). Developing the inquiry skills scale: validity and reliability study. Asian Journal of Instruction, 1(2), 56-65.

Alp, S., \& Taşkın, Ş. Ç. (2008). Importance of reflective thinking in education and developing reflective thinking. Milli Eğitim Dergisi, 178, 311-320.

Aşkın-Tekkol, İ., \& Bozdemir, H. (2018). An investigation of reflective thinking tendencies and critical thinking skills of teacher candidates. Kastamonu Education Journal, 26(6), 1897-1907. doi: 10.24106/kefdergi.2211.

Badger, J. (2010). Assessing reflective thinking: pre-service teachers' and professors' perceptions of an oral examination. Assessment in Education: Principles, Policy \& Practice, 17(1), 77-89.

Balım A.G., Deniş-Çeliker, H., Türkoğuz, S., Evrekli, E. \& İnel-Ekici D. (2015). The effect of concept cartoons supported problem based learning method on students' conceptual understanding levels and perceptions of problem solving skills. Journal of Turkish Science Education, 12(4), 53-76. doi:10.12973/tused.10151a

Balım, A. G., Inel, D., \& Evrekli, E. (2008). The effect of using concept cartoons in science teaching on students' academic achievement and perceptions of inquiry learning skills. Ilkogretim Online, 7(1), 188-202.

Balım, A., G., \& Taşkoyan, N. (2007). Developing an inquiry learning skills perception scale for science. Dokuz Eylül University Buca Faculty of Education Journal, 21, 58-63.

Baran, M., Baran, M., \& Maskan, A. (2018). Evaluation of science PISA test results of students in Turkey by physics teacher candidates. YYU Journal of Education Faculty, 15(1), 1517-1539. doi:10.23891/efdyyu.2018.114
Barrows, H., S. (1996). Problem-based learning in medicine and beyond: A brief overview. New directions for teacbing and learning, 68, 3-12. doi: $10.1002 / \mathrm{tl} .37219966804$

Başol, G., \& Evin-Gencel, I. (2013). Reflective thinking scale: a validity and reliability study. Educational Sciences: Theory and Practice, 13(2), 941-946.

Bayrak F., \& Usluer Y., K. (2011). The effect of blogging on reflective thinking skills. Hacettepe University Journal of Education Faculty, 40, 93104.

Bell, R. L., Smetana, L., \& Binns, I. (2005). Simplifying inquiry instruction. The science teacher, 72(7), 30-33.

Belland, B., R., (2010). Portraits of middle school students constructing evidence-based arguments during problem-based learning: The impact of computer-based scaffolds. Educational technology research and Development, 58(3), 285-309. doi: 10.1007/s11423-009-9139-4

Bezen, S., \& Bayrak, C. (2020). Determining Students' Attitudes and Views Using an Inquiry-Based Learning Approach. Cukurova University Faculty of Education Journal,49(2), 555-599. doi: 10.14812/cufej.676679

Bozan, S. (2021). Determining students' reflective thinking levels and examining their reflections on science concepts. African Educational Research Journal, 9(2), 544-550. doi: 10.30918/AERJ.92.21.070

Cansoy, R. (2018). Uluslararası Çerçevelere Göre 21.Yüzyıl Becerileri ve Eğitim Sisteminde Kazandırılması. Insan ve Toplum Bilimleri Arastirmalar Dergisi, 7 (4), 3112-3134. doi: 10.15869/itobiad.494286

Cantürk-Günhan, B., \& Başer, N. (2009). The effect of problem-based learning on students' critical thinking skills. Journal of Turkish Educational Sciences, $7(2)$, https://dergipark.org.tr/tr/pub/tebd/issue/26107/275071

Chee-Choy, S., \& San Oo, P. (2012). Reflective thinking and teaching practices: A precursor for incorporating critical thinking into the classroom? International Journal of Instruction, 5(1), 167-181. https:// files.eric.ed.gov/ fulltext/ED529110.pdf

Creswell, J. W. (2003). Qualitative, Quantitative and Mixed Methods Approaches. Thousand Oaks, CA: Sage Publications.

Cuevas, P., Lee, O., Hart, J. and Deaktor, R. (2005). Improving science inquiry with elementary students of diverse backgrounds. Journal of Research in Science Teaching, 42(3), 337-357. doi: 10.1002/tea.20053

Dadli, G. (2017). The effect of learning activities based on authentic problems in the buman and environmental relations unit on the reflective thinking skills, academic success, environmental attitude and awareness of 7 th grade students. (Unpublished Master's thesis), Kahramanmaraş Sütçü İmam University, Kahramanmaraş.

Dahlgren, M., A., \& Öberg, G. (2001). Questioning to learn and learning to question: Structure and function of problem-based learning scenarios in environmental science education. Higher education, 41(3), 263-282. doi: 10.1023/A:1004138810465

Demiralp, D. (2010). Teachers' views on the effect of primary education programs on improving students' reflective thinking (Example of Elarig Province). (Unpublished Master's Thesis), Firat University Institute of Social Sciences, Elazig.

Demiralp, D., \& Kazu, H. (2012). Ilkogretim birinci kademe programlarının ogrencilerin yansıtıcı dusunmelerini gelistirmedeki katkısına yonelik ogretmen gorusleri. Pegem Egitim ve Ogretim Dergisi, 2(2),

29-38. https://dergipark.org.tr/tr/pub/pegegog/issue/22589/241276

Demirel, M., Derman, I., \& Karagedik, E. (2015). A study on the relationship between reflective thinking skills towards problem solving and attitudes towards mathematics. Procedia-Social and Behavioral Sciences, 197, 2086-2096. doi: 10.1016/i.sbspro.2015.07.326

Deniş-Çeliker, H. (2021). Problem-based Scenario Method with Experiments: Determining the Prospective Science Teachers' Biology Self-efficacy and Critical Thinking Tendency. Science Education International, 32(1), 23-33. doi: 10.33828/sei.v32.11.3

Duru, M., K., Demir, S., Önen, F., \& Benzer, E. (2011). The effect of inquiry-based laboratory applications on pre-service teachers' 
attitude towards laboratory perception and scientific process skills. Atatürk Faculty of Education Journal of Educational Sciences, 33, 25-44. http://dspace.marmara.edu.tr/bitstream/handle/11424/853/904 -1756-1-SM.pdf?sequence $=1$ \&isAllowed $=\mathrm{y}$

Dolapçığlu, S. (2020). The effect of thinking classroom materials (DSM) on PISA reading skills. Ana Dili Eğitimi Dergisi, 8(1), 196210. doi: $10.16916 /$ aded. 658510

Durdukoca, F. Ş., \& Demir, M. (2012). The reflective thinking levels of primary school teachers according to some variables and the suitability of teacher qualifications in their thoughts with reflective teacher qualifications. Mustafa Kemal University Institute of Social Sciences, 9(20), 357-374. https://dergipark.org.tr/tr/pub/mkusbed/issue/19549/208417

Ekiz, D. (2006). Self-Observation and Peer-Observation: Reflective Diaries of Primary Student-Teachers. Elementary Education Online, 5(1), 45-57. https://dergipark.org.tr/en/download/articlefile/91061

Epstein, A. S. (2003). How Planning and Reflection Develop Young Children's Thinking Skills. Young children, 58(5), 28-36. https://eric.ed.gov/?id=EJ679112

Erdoğan, A. (2019). Examination of secondary school students' reflective thinking skills for problem solving in terms of some variables (Unpublished master's thesis). Necmettin Erbakan University, Konya.

Erdoğan, F. (2020). The relationship between prospective middle school mathematics teachers' critical thinking skills and reflective thinking skills. Participatory Educational Research, 7(1), 220-241. doi: $\underline{10.17275 / \text { per.20.13.7.1 }}$

Firman, M., \& Ertikanto, C. \& Abdurrahman, A. (2019). Description of meta-analysis of inquiry-based learning of science in improving students' inquiry skills. Journal of Physics: Conference Series, 1157, 1-7. doi:10.1088/1742-6596/1157/2/022018

Harlen, W. (2004). Evaluating inquiry-based science developments: a paper commisisoned by the national reasearch council in preparation for a meeting on the status of evaluation of inquirybased science education. Cambridge: National Academy of Sciences. Education, 26(1),

$14-17$. http://www7.nationalacademies.org/bose/WHarlen_inquiry_Mt g_paper.pdf.

Hmelo, C. E., \& Ferrari, M. (1997). The problem-based learning tutorial: Cultivating higher order thinking skills. Journal for the Education of the Gifted, 20(4), 401-422. doi: 10.1177/016235329702000405

Hmelo-Silver, C. E. (2004). Problem-based learning: What and how do students learn?. Educational psychology review, 16(3), 235-266. doi: 10.1023/B:EDPR.0000034022.16470.f3

Hoffman, B., \& Spatariu, A. (2011). Metacognitive prompts and mental multiplication: Analyzing strategies with a qualitative lens. Journal of Interactive Learning Research, 22(4), 607635. https://www.learntechlib.org/primary/p/35341/.

Hofstein, A., \& Lunetta, V. N. (2004). The laboratory in science education: Foundations for the twenty-first century. Science education, 88(1), 28-54. doi: 10.1002/sce.10106

Hofstein, A., Shore, R., \& Kipnis, M. (2004). Providing high school chemistry students with opportunities to develop learning skills in an inquiry-type laboratory: A case study. International Journal of Science Education, 26(1), 47-62. doi: 10.1080/0950069032000070342

Hofstein, A., Navon, O., Kipnis, M., \& MamlokNaaman, R. (2005). Developing students' ability to ask more and better questions resulting from inquiry-type chemistry laboratories. Journal of Research in Science Teaching, 42(7), 791-806. doi:10.1002/tea.20072

Howe, A., C. (2002). Engaging Children in Science (3rd ed.). Upper Saddle River, NJ: Werrill Prentice Hall.

Howes, E., V., Lim, M., \& Campos, J. (2009). Journeys into inquirybased elementary science: Literacy practices, questioning, and empirical study. Science Education, 93(2), 189-217. doi: $10.1002 /$ sce. 20297
Huang, S., H., Huang, Y., M., Wu, T., T., Chen, H., R., \& Chang, S., M. (2016). Problem-based learning effectiveness on micro-blog and blog for students: a case study. Interactive Learning Environments, 24(6), 1334-1354. doi: $10.1080 / 10494820.2015 .1004353$

Hung, W., Jonassen, D. H., \& Liu, R. (2008). Problem-based learning. In J. M. Spector, J. G. van Merriënboer, M. D., Merrill, \& M. Driscoll (Eds.), Handbook of research on educational communications and technology (3rd, pp. 485-506). Mahwah: Erlbaum.

Hwang, G. J., Kuo, F. R., Chen, N. S., \& Ho, H. J. (2014). Effects of an integrated concept mapping and web-based problem-solving approach on students' learning achievements, perceptions and cognitive loads. Computers \& Education, 71, 77-86. doi: 10.1016/i.compedu.2013.09.013

Ioannou, A., Brown, S. W., Hannafin, R. D., \& Boyer, M. A. (2009). Can multimedia make kids care about social studies? The GlobalEd problem-based learning simulation. Computers in the Schools, 26(1), 63-81. doi: $10.1080 / 07380560802688299$

Inel, D. (2009). The effects of the using of problem based learning method in science and technology course on students' the levels of constructing concepts, academic achievement and enquiry learning skill perceptions. Master of Thesis, Dokuz Eylül University, İzmir.

Inel, D. (2012). The effects of problem-based learning method supported by concept cartoons on students' perceptions of problem solving skills, motivation for science learning and conceptual understanding. $\mathrm{PhD}$ Thesis, Dokuz Eylül University, İzmir.

İnel-Ekici, D. (2017). Ortaokul öğrencilerinin bilimsel sorgulama becerileri algılarını etkileyen faktörlerin incelenmesi. Kastamonu Eğition Dergisi, $25 \quad$ (2), 497-516. https://dergipark.org.tr/en/download/article-file/302519

Johnstone, A., H., \& Otis, K., H. (2006). Concept mapping in problem based learning: a cautionary tale. Chemistry Education Research and Practice, 7(2), 84-95. doi: 10.1039/B5RP90017D

Junsay, M., L. (2016). Reflective learning and prospective teachers' conceptual understanding, critical thinking, problem solving, and mathematical communication skills. Research in Pedagogy, 6(2), 43-58.

Kamin, C. S., O'Sullivan, P. S., Younger, M., \& Deterding, R. (2001). Measuring critical thinking in problem-based learning discourse. Teaching and learning in medicine, 13(1), 27-35. doi: $\underline{10.1207 / \text { S15328015TLM1301 } 6}$

Kang, N. H., DeChenne, S. E., \& Smith, G. (2012). Inquiry learning of high school students through a problem-based environmental health science curriculum. School Science and Mathematics, 112(3), 147-158. doi: $10.1111 /$ i.1949-8594.2011.00128.x

Karamustafaoğlu, S., \& Havuz, A. C. (2016). Inquiry based learning and its effectiveness. International Journal of Assessment Tools in Education, 3(1), 40-54. https://dergipark.org.tr/en/pub/ijate/issue/22371/239553

Karaoğlan-Yilmaz, F. G., \& Keser, H. (2016). The impact of reflective thinking activities in e-learning: A critical review of the empirical research. Computers \& Education, 95, 163-173. doi: 10.1016/i.compedu.2016.01.006

Karasar, N. (2003). Bilimsel araștırma yöntemi: Kavramlar, ilkeler, teknikler.[Scientific research method: Concepts, principles, techniques]. Ankara, Turkey: Nobel Yayın Dağıtım.

Katranc1, Y., \& Şengül, S. (2020). Evaluating the inquiry learning skills towards math of middle school students in terms of questioning, evaluating, reasoning and reflective thinking skills towards problem solving. Education and Science, 45(201), 55-78. doi: 10.15390/EB.2020.7765

Kazu, H., \& Demiralp, D. (2012). Usage status of methods that enhance reflective thinking in primary level programs (Elazığ city example). International Online Journal of Educational Sciences, 4(1), 131145.

Kember, D., Leung, D., Jones, A., Loke, A., McKay, J., Sinclair, K., Tse, H., Webb, C., Wong, F., Wong, M., \& Yeung, E. (2000). Development of a questionnaire to measure the level of reflective 
thinking. Assessment and Evaluation in Higher Education, 25, 381-395. doi: $10.1080 / 713611442$

Kholid, M. N., Sa'dijah, C., Hidayanto, E., \& Permadi, H. (2020). How are students' reflective thinking for problem solving? Journal for the Education of Gifted Young Scientists, 8(3), 1135-1146. doi: 10.17478/jegys.688210

Kızılkaya, G., \& Asskar, P. (2009). The development of a reflective thinking skill scale towards problem solving. Education and Science, 34(154), 82-92.

King, P. M., \& Kitchener, K. S. (2004). Reflective judgment: Theory and research on the development of epistemic assumptions through adulthood. Educational psychologist, 39(1), 5-18. doi: $10.1207 / \mathrm{s} 15326985 \mathrm{ep} 3901 \_2$

Kuhn, D. (1990). Developmental perspectives on teaching and learning thinking skills. New York: Jossey-Bass.

Lee, O., Hart, J. E., Cuevas, P., \& Enders, C. (2004). Professional development in inquiry-based science for elementary teachers of diverse student groups. Journal of research in science teaching, 41(10), 1021-1043. doi: $10.1002 /$ tea.20037

Lu, J., Lajoie, S. P., \& Wiseman, J. (2010). Scaffolding problem-based learning with CSCL tools. International Journal of Computer-Supported Collaborative Learning, 5(3), 283-298. doi: 10.1007/s11412-0109092-6

Maaß, K., \& Artigue, M. (2013). Implementation of inquiry-based learning in day-to-day teaching: A synthesis. ZDM Mathematics Education, 45(6), 779-795. doi: 10.1007/s11858-013-0528-0

Mansvelder-Longayroux, D., Beijaard, D., Verloop, N., \& Vermunt, J. (2007). Functions of the learning portfolio in student teachers' learning process. Teachers College Record, 109(1), 126-159. https://www.tcrecord.org/PrintContent.asp?ContentID=12738

Marklin-Reynolds, J., \& Hancock, D. R. (2010). Problem-based learning in a higher education environmental biotechnology course. Innovations in Education and Teaching International, 47(2), 175186. doi: $10.1080 / 14703291003718919$

Mezirow, J. (1997). Transformative learning: Theory to practice. New directions for adult and continuing education, 74, 5-12. doi $10.1002 /$ ace. 7401

Ministry of National Education. (2009). International student assessment program PISA 2009 national preliminary report. http://pisa.meb.gov.tr/?page_id $=22$

Ministry of National Education. (2011a). TIMSS 2011 national math and science report 4 th http://timss.meb.gov.tr/www/raporlar/icerik/3

Ministry of National Education. (2011b). TIMSS 2011 national math and science report 8th grade. http://timss.meb.gov.tr/www/raporlar/icerik/3

Ministry of National Education. (2012). PISA international student assessment program PISA 2012 research national final report. http://pisa.meb.gov.tr/?page_id=22

Ministry of National Education (2013). Primary education institutions science lesson curriculum. Ankara: Board of Education and Discipline.

Ministry of National Education. (2015a). International student assessment program PISA 2015 national report. http://pisa.meb.gov.tr/?page_id=22.

Ministry of National Education. (2015b). TIMSS 2015 national math and science preliminary report 4 th and 8 th grades. http://timss.meb.gov.tr/www/raporlar/icerik/3

Ministry of National Education. (2018). PISA 2018 Turkey preliminary report. http://pisa.meb.gov.tr/?page_id=22

Namvar, Y., Naderi, E., Shariatmadari, A., \& Seifnaraghi, M. (2009). Studying the impact of web-based learning (weblog) with a problem solving approach on student's reflective thinking. International Journal of Emerging Technologies in Learning, 4(2), 33-38. https://www.learntechlib.org/p/45012/.

Okumuş, S., \& Yetkil, K. (2020). Ortaokul öğrencilerinin sorgulama becerilerinin değerlendirilmesi. Bayburt Ë̆itim Fakültesi Dergisi, 15(30), 508-526. doi: 10.35675/befdergi.740348.
Onan, A. (2013). The effect of problem based networked learning on the medical students' selfefficacy perception. Educational Sciences and Practice, 12 (24), 77-94.

Organisation for Economic Co-operation and Development (OECD). (2018). The future of education and skills: Education 2030. https://www.oecd.org/education/2030/E2030\%20Position \%20 Paper $\% 20$

Panasan, M., \& Nuangchalerm, P. (2010). Learning Outcomes of Project-Based and Inquiry-Based Learning Activities. Journal of Social Sciences, 6(2), 252-255. https:// files.eric.ed.gov/fulltext/ED509723.pdf

Pusmaz, A., \& Tavşan, S. (2019). The analysis of reflective thinking skill toward problem solving of students with good at solving problems. Kastamonu Education Journal, 27(2), 837-852.

Reaume, R. (2011). Pre-service teacher perceptions of and experiences with the implementation of inquiry based science teaching (Order No. MR76264). Available from ProQuest Dissertations \& Theses Global. (916791964). https://www.proquest.com/dissertationstheses/pre-service-teacher-perceptions-experienceswith/docview/916791964/se-2?accountid $=37161$

Rieger, A., Radcliffe, B. J., \& Doepker, G. M. (2013). Practices for developing reflective thinking skills among teachers. Kappa Delta Pi Record, 49(4), 184-189. Doi:10.1080/00228958.2013.845510

Saygll, G., \& Atahan, R. (2014). Examining reflective thinking skills of gifted children for problem solving in terms of various variables. Süleyman Demirel University Faculty of Arts and Sciences Journal of Social Sciences, 31 , 181-192. https://dergipark.org.tr/en/pub/sufesosbil/issue/11406/136178

Stotter, J., \& Gillon, K. (2011). Inquiry learning with senior secondary students: yes it can be done!. Access, 25(3), 14-19. doi: 10.3316/informit.341090467276495

Smith, C. S., \& Hung, L. C. (2017). Using problem-based learning to increase computer self-efficacy in Taiwanese students. Interactive Learning Environments, 25(3), 329-342. doi: $10.1080 / 10494820.2015 .1127818$

Song, H. D., Grabowski, B. L., Koszalka, T. A., \& Harkness, W. L. (2006). Patterns of instructional-design factors prompting reflective thinking in middle-school and college level problembased learning environments. Instructional Science, 34(1), 63-87. doi: $10.1007 /$ s11251-005-6922-4

Taşkın-Can, B., \& Yıldırım, C. (2014). The instrument for determining the levels of reflective thinking among elementary school students. Educational Research and Reviews, 9(1), 9-16. doi: 10.5897/ERR12.093

Taşkoyan, S. N. (2008). The effect of inquiry learning strategies in science and technology teaching on students' inquiry learning skills, academic achievements and attitudes. Master of Thesis, Dokuz Eylül University, Izmir.

Uden, L., \& Beaumont, C. (2006). What Is problem-based learning? In L. Uden \& C. Beaumont (Eds.), Technology and problem-based learning (pp. 25-43). London: IGI Global.

Usta, N., Mirasyedioğlu, S.., \& Tarihi, M. G. (2017). The effect of mathematics teaching with problem-based learning approach on 7th grade students' mathematics achievement and self-efficacy. Kastamonu Education Journal, 25(6), 2263-2282.

Van der Schaaf, M., Baartman, L., Prins, F., Oosterbaan, A., \& Schaap, H. (2013). Feedback dialogues that stimulate students' reflective thinking. Scandinavian Journal of Educational Research, 57(3), 227-245. doi: $10.1080 / 00313831.2011 .628693$

Wilson J. \& Jan W. L. (1993). Thinking for themselves developing strategies for reflective learning, Australia: Eleanor Curtain Publishing.

Wood, W. B. (2003). Inquiry-based undergraduate teaching in the life sciences at large research universities: a perspective on the Boyer Commission Report. Cell Biology Education, 2(2), 112-116. doi: 10.1187/cbe.03-02-0004

Wopereis, I., Brand-Gruwel, S., \& Vermetten, Y. (2007). The effect of embedded instruction on solving information problems. Computers in Human Behavior, 24(3), 738-752. doi: 10.1016/i.chb.2007.01.024

Wu, H. K., \& Hsieh, C. E. (2006). Developing sixth graders' inquiry skills to construct explanations in inquiry-based learning 
environments. International journal of science education, 28(11), 12891313. doi: $10.1080 / 09500690600621035$

Yaşar, Ş., \& Duban, N. (2009). Students' opinions regarding to the inquiry-based learning approach. İlkögretim Online, 8(2), 457-475.

Yenilmez, K. \& Turgut, M. (2016). Relationship between prospective middle school mathematics teachers' logical and reflective thinking skills. Journal of Educational and Instructional Studies in the World, 6(4), 15-20.

Yildirım, C., \& Can, B. (2018). The effect of argumentation supported problem-based learning on students' inquiry learning skil perceptions. Pamukkale University Journal of Education, 44, 251-277. doi: 10.9779/PUJE.2018.217

Yildiz, N. (2010). The effects of experimental practices in solving problem-based learning scenarios in science education on students' success, attitudes and scientific process skills. (Unpublished Master Thesis). Istanbul: Marmara University Institute of Educational Sciences.

Zion, M. I., \& Sadeh, I. (2007). Curiosity and open inquiry learning. Journal of Biological Education,41(4), 162-169. doi: $\underline{10.1080 / 00219266.2007 .9656092}$ 